\title{
Research on the Cultivation Model of Applied Talents in Private University against the Background of Transformation
}

\author{
Ping Ju \\ Fuzhou University of International Studies and Trade, \\ Fuzhou, Fujian 350202
}

\begin{abstract}
With the improvement of colleges and universities' ability to serve local economic development, the needs of applied talents is increasing gradually. Therefore, the colleges and universities actively respond to focus on the construction of application-oriented colleges and universities. As a new private university, Fuzhou University of International Studies and Trade actively transform to applied university for the purpose of cultivating applied high-quality talents. Fuzhou University of International Studies and Trade organizes specialty group to explore the cultivation mode of applied talents. This paper takes the international trade specialty group as an example, analyzes talents cultivation mode, combines specialized knowledge with practices in enterprises, concludes existing problems and puts forward the countermeasures.
\end{abstract}

Keywords-Private university; Applied talents; Specialty group; Talents training mode

\section{INTRODUCTION}

With the development of over 40 years, the popularization of higher education and the complement of plenty of private colleges and universities cause many problems such as unidisciplinary talents cultivation, being strict at enrolment but slack at graduation and demand gap, etc. To solve the above problems, in February of 2014, in the executive meeting, Premier of the State Council, Li Keqiang points out that it is necessary to accelerate the development of modern vocational education and guild the colleges and universities to transform to the applied technology-based colleges and universities. Therefore, provincial departments of education devote major efforts to develop the application-oriented disciplines and specialty groups. As a new private university and one of application-oriented pilot university, Fuzhou University of International Studies and Trade adheres to the principle of ability first and focuses on the cultivation of applied talents. [1]

Fujian Province plays a leading role in the development of open economic system and has formed industry groups mainly including international commerce industry, shipping industry, modern logistics and financial service industry. China (Fujian) Pilot Free Trade Zone Industry Development Planning (20152019) points out that it is necessary to focus on the development of seven industrial clusters which include commerce industry. To better serve the local economy and meet the industrial needs, based on the principle of resource sharing, system integration and advancing on the whole, in Fuzhou University of International Studies and Trade, specialty of international economy and trade and foreign language specialty (including English, French, Japanese and Translation) established the specialty group of international commerce applied talents cultivation [2].

\section{CURRENT Situation OF APPLIED TALENTS CULTIVATION OF INTERNATIONAL COMMERCE SPECIALTY GROUP}

\section{A. Causes and Effects of International Commerce Specialty Group}

Based on the principle of resource sharing, system integration and advancing on the whole, the four specialties included in the international commerce specialty group could fully exploit the advantages of specialty group, enhance the foreign language levels, qualities and capabilities of students of specialty of international economy and trade, better meet the requirements of professional abilities and enhance the competitiveness of applied talents cultivated by international commerce specialty group.

The specialty group serves the international trade industry chain including international sale of goods, international service trade, cross-border e-commerce and economic cooperation between Fujian and Taiwan under the background of the development of open economic system in Fuzhou. Its purpose is to cultivate the interdisciplinary applied talents with international perspectives, qualified business ability, strong ability of application of foreign languages and skills of expertly use the international trade ability to finish the related works.

International commerce specialty group has clear goals in cultivating applied talents. According to the results of talent demand survey, the local employers in Fujian pay much attention to the compound ability of business ability and foreign language application. Therefore, the specialty group aims at cultivating international trade talents, intensifying vocational training, highlighting regional characteristics of Fujian, combining the international trade practice ability and foreign language application and building a " $1+2$ " (professional quality + business ability + foreign language application) new three-dimensional talent cultivation mode [3]. 
International commerce specialty group covers 4 specialties, 63 classes and 2303 students. There are 61 classes and 2144 students participated in applied talent cultivation, including 12 classes and 510 freshmen, 14 classes and 442 sophomores, 17 classes 575 juniors and 18 classes 587 seniors. Up to June in 2017, leading teachers have established 4 teaching teams for applied talents cultivation, completed the reconstruction of 13 courses , modularized teaching of 5 courses, case library construction 6 courses, and 4cources on MOOK, and established the practice platform (Table 1 ) for foreign trade closely cooperate with six powerful enterprises; There are 35 students of specialty group won national level competition per time, 105 students won provincial competition per time, over 100 teaching and research projects.

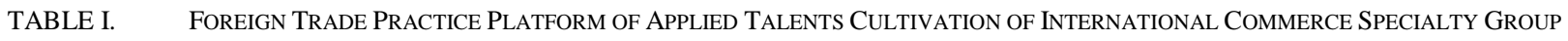

\begin{tabular}{|c|c|c|c|c|c|c|}
\hline $\begin{array}{l}\text { Name of } \\
\text { Specialty } \\
\text { Group }\end{array}$ & Name of Platform & Partner & $\begin{array}{l}\text { Capital } \\
\text { invested in } \\
2016 \text { (Yuan) }\end{array}$ & $\begin{array}{l}\text { Capital } \\
\text { source }\end{array}$ & Specialty & Industry \\
\hline \multirow{8}{*}{$\begin{array}{l}\text { Applied } \\
\text { Talents } \\
\text { Cultivation of } \\
\text { International } \\
\text { Commerce } \\
\text { Specialty } \\
\text { Group }\end{array}$} & $\begin{array}{l}\text { OTO E-commerce Hatch } \\
\text { Public Service Platform }\end{array}$ & $\begin{array}{l}\text { Fujian Wuyou } \\
\text { Science and } \\
\text { Technology Ltd. }\end{array}$ & 2000,000 & $\begin{array}{l}\text { Cooperative } \\
\text { enterprises }\end{array}$ & $\begin{array}{l}\text { International } \\
\text { Economics and Trade, } \\
\text { English, Japanese, } \\
\text { French }\end{array}$ & $\begin{array}{l}\text { Cross-border } \\
\text { E-commerce }\end{array}$ \\
\hline & \multirow[t]{3}{*}{$\begin{array}{l}\text { "Zhenghan International” } \\
\text { International Trade Public } \\
\text { Service Practice Platform }\end{array}$} & \multirow[t]{3}{*}{$\begin{array}{l}\text { Fuzhou Zhenghan } \\
\text { Automation Ltd. }\end{array}$} & \begin{tabular}{|l} 
Education \\
Department \\
160,000 \\
University \\
160,000 \\
\end{tabular} & $\begin{array}{l}\text { Education } \\
\text { Department }\end{array}$ & \multirow{3}{*}{$\begin{array}{l}\text { International } \\
\text { Economics and Trade, } \\
\text { English, Japanese, } \\
\text { French }\end{array}$} & $\begin{array}{l}\text { International } \\
\text { trade }\end{array}$ \\
\hline & & & $\begin{array}{l}\text { Enterprise } \\
100,000\end{array}$ & University & & $\begin{array}{l}\text { Mechano- } \\
\text { electronic }\end{array}$ \\
\hline & & & & Enterprise & & \\
\hline & \multirow[b]{2}{*}{$\begin{array}{l}\text { Alibaba Changle Foreign } \\
\text { Trade Talent Training } \\
\text { Platform }\end{array}$} & \multirow[b]{2}{*}{$\begin{array}{l}\text { Alibaba Changle } \\
\text { Service Center }\end{array}$} & 100,000 & Enterprise & \multirow{2}{*}{$\begin{array}{l}\text { International } \\
\text { Economics and Trade, } \\
\text { English, Japanese, } \\
\text { French }\end{array}$} & \multirow[b]{2}{*}{$\begin{array}{l}\text { Foreign } \\
\text { Trade, Textile } \\
\text { Industry }\end{array}$} \\
\hline & & & 100,000 & University & & \\
\hline & $\begin{array}{l}\text { Lijia Trade Mart Cross- } \\
\text { border Electronic Service } \\
\text { Platform }\end{array}$ & Lijia Trade Mart & & & $\begin{array}{l}\text { International } \\
\text { Economics and Trade, } \\
\text { English, Japanese, } \\
\text { French }\end{array}$ & $\begin{array}{l}\text { Cross-border } \\
\text { E-commerce }\end{array}$ \\
\hline & $\begin{array}{l}\text { Zhongrui Network } \\
\text { Education Platform }\end{array}$ & $\begin{array}{l}\text { Zhongrui Network } \\
\text { Technology Ltd }\end{array}$ & & & $\begin{array}{l}\text { International } \\
\text { Economics and Trade, } \\
\text { English, Japanese, } \\
\text { French }\end{array}$ & $\begin{array}{l}\text { High- } \\
\text { technology, } \\
\text { Education }\end{array}$ \\
\hline
\end{tabular}




\section{B. Features and Improvement Measures of Applied Talents Cultivation of International Commerce Specialty Group}

1) Common Construction of Teaching Case Industry and Textbook Compilation by University-Enterprise Cooperation

Teachings by cases are the key issue of applied courses transformation. The university cooperated with enterprises to collate the practical cases of enterprises, establish the international commerce and trade specialty group case library including 25 cases such as "international trade single window", which could applied to the teaching links of related courses, enhance learning effect and help students to apply the theoretical knowledge in practical business. The university and enterprises, such as Zhongrui Network Technology Ltd., make joint efforts to build teams and compile several textbooks which reveal true practices and processes of commerce and trade. 13 textbooks and readers have been published, including Documents Business of Foreign Trade. The school-based teaching textbooks such as International Trade Single Window have been put into continuous use for two years. The textbooks mentioned above are also used intensively by cooperative enterprises using as inner training materials.

2) The University and Enterprises Make Joint Efforts to Build the Applied Teaching Team

The construction mode of teaching team with "double quality and double ability" is flexible and diverse. Cultivate the quality and operational capacity of teachers. Select several teachers of international commerce and trade specialty to take a temporary post and to be trained in enterprises, and select excellent teachers of international commerce and trade specialty to take a temporary post and to be trained in governmental competent departments. In the meantime, augment the teaching team by introducing qualified administrative staff and technical experts in enterprises, doctors with years of enterprise practical experience and business elites familiar with regional economy and technical industrial industry, and three teachers coming from Taiwan in order to take advantage of there practical experience and learn the experience in cultivating applied talents.

3) Enhance the Integration between University and Enterprises, Establish University-enterprise Practice Platform

The specialty group found out the demands of university and enterprises, integrated the enterprise resources take Zhongrui Network Technology as the core, and established the cross-border e-commerce industry college. The university cooperated with enterprises to establish training program and teaching team, establish shared teaching resources and practical training platforms of industry college. The management mode of "co-construction, co-management, sharing, win-win and sustainability" is well developed gradually. The industry college introduced the enterprise culture of "integrative development", integrated with school motto of "Sino-foreign Integration for the Purpose of Application ", transformed the Cross-Cultural Communication course, increased knowledge and skill training such as international business etiquette and communication skills, created Business Cross-Cultural Communication course, and promoted the intercultural business communication skill of students systematically. The specialty group has established cross-border e-commerce lab and built university-enterprise cooperation practice platform with joint efforts of Zhongrui Network Technology Ltd.

4) Innovate University-enterprise Co-construction and Sharing Mechanism and Enhance the Application Ability of Students

To meet the demands of commercial and trade development of Fujian province, the specialty group investigated with experts in industry and enterprises, planned to add specialties such as international business and Spanish. In principal of "coconstruction and sharing", construct 5 new labs, transform and upgrade 11 labs and co-construct 2 specialty group experimental platforms. Promote the diversification of evaluation mode, evaluation methods and evaluation subject of courses of specialty group. Introduce the talents of enterprises to participate in examination and evaluation. The teachers participate in the evaluation of practical courses and experimental courses. The application ability of students shall be evaluated from the perspective of "business process" in order to enhance the rationality of evaluation. There are 13 courses have finished the reformation of assessment mode including practice of international trade. [4]

\section{EXISTING PROBLEMS OF APPLIED TALENT CUlTIVATION IN PRIVATE UNIVERSITY}

\section{A. Incomplete Concept Transformation}

The target of cultivating applied talents is clear. However, part of teaching and administrative staff are passive in transformation for the unclear understanding of the goals of applied talent cultivation, especially the way of realizing it, insufficient understanding and research of how to adapt to the industry transformation and upgrading, talent supply-demand relationship changes and innovation-driven development.

\section{B. Insufficient Support of University-enterprise Integration}

The insufficient social force and insufficient participation of enterprises in designing and proving the training program in the process of transformation cause the inadequate integration of university and social resources, no breakthrough in the construction of industry institute and inadequate extent and depth of university-enterprise integration.

\section{Inadequate Teachers for Applied Talent Cultivation}

The teachers with double quality, double ability, industry background and occupational qualifications are less. The teachers who take a temporary post in enterprise and public institution are less. The teachers' expert in experiments and technicians is inadequate. Part of teachers is incompetent in serving the local. Part of teachers focus on teaching theories instead of practices, inadequate applicability of teaching for lacking practical experience and guidance ability, which could not meet the requirements of applied talent cultivation. 
D. Complicated Appraisement and Engagement Qualification Inspecting Which Could Not Meet the Actual Requirements

The application-oriented university shall introduce teachers with abundant business experiences. Therefore, the university has established corresponding rules and regulations. However, in reality, especially for foreign trade industry, the enterprise personnel lacks the education background required by the university while foreign trade sales with 10 years of experience and practical skills. [5]

\section{IMPROVEMENT MEASURES OF APPLIED TALENT CUlTivation IN PRIVATE UNIVERSITY}

\section{A. Further Free Minds and Update Educational Concept}

Further organize the discussion of educational thought, educational concept, transformation and development of specialty group. Through symposiums, seminars, forums and theme activities such as teaching quality month, guild the teachers of specialty group to learn and implement Instructions on Transform the Colleges and Universities to Applicationoriented Type issued by Minister of Education, Notice on Carrying out the Pilot Work of the Transformation of Colleges and Universities to Application-oriented Type (Fujian) and Special Plan for the Development of Education in the 13th Five-Year Plan in Fujian Province, etc. It is necessary to deeply understand the new situation of reform and development of higher education and new deployment of local economy transforming and upgrading development, deeply and thoroughly understand the theory on school management of application-oriented colleges and universities. The universities shall actively adapt to the new normal of economic development and integrate with local industry transformation and upgrading and innovation-driven development, thoroughly change the concepts to develop the applied talent cultivation and serve the local economy development.

\section{B. Take Cooperative Cultivation as Important Mechanism in Transformation}

It is necessary for universities to deepen the reformation of applied talent cultivation mode, that is university-enterprise cooperative cooperation, formulate training program make joint efforts to develop the course resources, implement cultivation process, evaluate cultivation quality with enterprises and spare no efforts to integrate the occupational qualification standard with training of professional talents. Reconstruct the talent training standard, course system, teaching content, teaching methods and examination and evaluation ways in order to meet occupational demands, improve vocational ability and continuously improve the learning ability of students.

\section{Improve the Applied Research and Technological Innovative Ability to Serve the Regional Development}

It is necessary to focus on the regional economic society development planning and industry transformation and upgrading in Fuzhou, actively integrate with regional and industrial technology innovation system, further support the development of applied scientific research, establish industrial common technology research and development center with regional characteristics, try to be a regional and industrial science and technology service base and technological innovation base. Explore the university-enterprise and university-local government collaborative and innovative longterm mechanism, including project research and development, technological breakthrough and achievement transformation. Establish industry institute integrated with enterprises and university. Explore advanced technology expand and industrialization ways, cooperate with scientific research institution and application-oriented colleges and universities to popularize the application of new technologies to small and medium-sized enterprises and to improve their technology application ability.

\section{Improve Appraisement and Engagement Qualification Inspecting System and Promote the Construction of Teaching Staff with "Double Quality and Double Ability"}

Specify the appraisement and engagement qualification inspecting system of enterprise talents teaching in the university, combine the practical situation to formulate the appraisement and engagement qualification inspecting system which could give play to the advantages of experiments of enterprise personnel and meet the requirements of applicationoriented talent cultivation in colleges and universities. In the process of training teachers with "double quality and double ability", focus on the improvement of practical ability and implement the training system, guild and support teachers to participate in professional qualification training to obtain professional qualification certificate, reform the appraisement and engagement qualification inspecting system, and assess the professional (vocational) training situation of teachers.[6]

\section{CONCLUSION}

Under the background of transformation, the private universities shall take advantage of flexible systems, carefully and actively implement the technical talent cultivation mode according to the development situation of industries and demands of the society, lay solid foundation in cultivating applied talents and enhance competitiveness continuously.

\section{ACKNOWLEDGMENT}

Project of production and study cooperation education (2nd Batch), Department of Higher Education of Ministry of Education of China - Innovation and Entrepreneurship Education Reform in Specialty of International Economics and Trade (No. 201702068083) ; Supported by the Training Program of FuJian Excellent Talents in University (FETU); School-level project of Fuzhou University of International Studies and Trade (No. FWX16020); 


\section{REFERENCES}

[1] lin Zhu. Research on the Transformation of Local Newly-built Colleges and Universities to Application-oriented Type [D]. Master's Thesis of China West Normal University, April, 2016.

[2] Zuqiang Ji. Research on the Transformation of Local Colleges and Universities to Application-oriented Type [J]. Development Research, 1003-0670 (2018) 3-0104-05.

[3] Zhifeng Wang. Explore and Research on the Transformation of Local Colleges and Universities to Application-oriented TypeTake“Minjiang University”for Example [J]. Education and Examinations, No. 5, 2014.

[4] Xiulian Hu. Enlightenment from Taiwan Higher Vocational Education for Mainland Civilian-Run Applied Undergraduate Education [J]. Journal of Guangdong Polytechnic Normal University, 1672-402X (2018)01-0038-06.

[5] Di Chen. Development Status and Comparative Study of Twaiwan and Mainland Application-oriented Colleges and Universities [J]. Journal of Zhengzhou Institute of Aeronautical Industry Management (Social Science Edition), August, 2016, Volume 35, No. 4.

[6] Jianwei He, Shaoming Zeng. Research on the Cultivation Mode of the Application-oriented Personnel of Fujian-taiwan Universities in the Application Transformation Context of Colleges and Universities [J].

[7] Wushu Yanjiu, November, 2017, Volume 2, No. 11. 